\title{
PENGARUH PENGALAMAN AUDITOR DAN ORIENTASI ETIKA TERHADAP KEPUTUSAN ETIS AUDITOR NEGARA DENGAN KOMITMEN PROFESIONAL SEBAGAI VARIABEL INTERVENING
}

\author{
Niken Nindya Hapsari \\ Fakultas Ekonomi dan Bisnis Universitas Brawijaya Malang. \\ Email: niken_NH@yahoo.com/No Telephon. 08155517233
}

\begin{abstract}
The objective of this study to examine The influence of auditor experience and ethical orientation on making ethical decision of governmental auditor, using professional commitment as an intervening variable. This research was developed from research Butt (1988), Zeigenfuss dan Singhapakdi (1994) also Windsor and Ashkanasy (1995) by changing professional commitments as an intervening variable on making ethical decision of auditor. The research was conducted using survey methods of governmental auditor who worked on the State Audit Office of the Representative Office of East Java Province is distributed directly to the response rate of $85 \%$. The unit of analysis were auditors with 100 respondents as samples. The analysis data technique in testing the hypothesis is path analysis.The results of this study indicated that first, the experience of auditors, ethical orientation influenced professional commitment and ethical orientation also commitment influenced ethical decision, meanwhile the auditor's experience did not influence the ethical decision. Second, these finding suggested that the professional commitment as an intervening variable of auditor experience and ethical orientation to the auditor's consideration of ethical decisions.The results concluded the auditor's experience and ethical orientation are two important issues related to professional commitment and ethical decision making. In towards the previous auditor experience and high ethical orientation could improve with good professional commitments as well as ethical decisions.
\end{abstract}

Keywords: Auditor Experiences, Ethics Orientation, Professional Commitment and Ethical Decision

\section{PENDAHULUAN}

Penerapan Good Corporate Governance (GCG) sudah menjadi bagian dan prinsip pengelolaan usaha secara mendunia, namun dengan terjadi skandal Enron dan WorldCom dan selanjutnya skandal subprime mortage pada pertengahan 2000an di Amerika Serikat yang menimbulkan krisis keuangan secara global sampai dengan saat ini, menunjukkan bahwa etika bisnis yang dijalankan selama ini sebagian besar menggunakan cara tidak etis, praktik-praktik seperti kolusi, nepotisme dan praktik-praktik tidak etis lainnya masih dijalankan. 
Berkembangnya berbagai kecurangan di dunia usaha yang berskala dunia, juga terjadi di Indonesia. Berbagai skandal keuangan, korupsi, penyalahgunaan aset, serta perekayasaan laporan keuangan telah menjadi berita setiap hari di media massa, sehingga menjadi sorotan dan keprihatinan masyarakat Indonesia. Terungkapnya korupsi di pemerintahan menyita perhatian publik, seperti kasus Mulyana W. Kusumah, anggota Komisi Pemilihan Umum (KPU) pada awal bulan April 2005 yang diduga melakukan tindakan usaha penyuapan terhadap auditor Badan Pemeriksa Keuangan (BPK). Selain itu, kasus Bank Century pada tahun 2009 yang sampai sekarang belum selesai, serta kasus Gayus Tambunan yang menyeret nama dua lembaga perpajakan dan kepolisian pada tahun 2010. Kasus lain di pemerintahan juga terjadi, sesuai pemberitaan pada tanggal 3 Agustus 2010 bahwa Inspektorat Jenderal telah menerima 85 pengaduan penyimpangan di Kementerian Keuangan (Suprapto dan Latif, 2010). Penanganan terhadap pengaduan penyimpangan telah dilaksanakan sejak tahun 2005 oleh aparat Inspektorat Jenderal (Itjen) Kementerian Keuangan dan berhasil mengembalikan keuangan negara sebesar Rp 397,45 miliar serta merekomendasikan pengenaan sanksi terhadap pejabat atau pegawai yang melakukan pelanggaran. Berdasarkan adanya kasus-kasus di atas membuktikan betapa penting peningkatan etika dan komitmen auditor dalam menjalankan tugas.

Nugrahaningsih (2005) mengatakan, saat ini auditor menjadi sorotan publik karena antara lain praktik-praktik profesi dilaksanakan dengan mengabaikan standar akuntansi bahkan kode etik. Perilaku tidak etis merupakan isu relevan bagi profesi akuntan saat ini di Indonesia. Hal ini berkembang seiring dengan terjadinya beberapa pelanggaran kode etik, baik yang dilakukan oleh akuntan publik, akuntan internal maupun akuntan pemerintah. Perilaku-perilaku yang tidak sesuai dengan kode etik profesi auditor ini, tidak boleh dibiarkan terus-menerus terjadi karena akan merusak kepercayaan masyarakat terhadap profesi auditor. Oleh karena itu, tema tentang independensi dan etika dalam profesi akuntan juga memiliki pemahaman yang sangat penting dan mendalam dalam menjaga reputasi profesi akuntan. Untuk memulihkan kepercayaan masyarakat terhadap profesi akuntan maka, independensi dan etika dalam profesi akuntan merupakan suatu hal yang harus dijunjung tinggi oleh auditor dan merupakan sebuah keharusan dalam era sekarang ini. 
Terdapat beberapa lembaga yang bertanggung jawab secara fungsional atas pengawasan terhadap pengelolaan dan tanggung jawab keuangan negara di Indonesia. Pada tingkat tertinggi terdapat Badan Pemeriksa Keuangan (BPK), Badan Pengawasan Keuangan dan Pembangunan (BPKP) dan Inspektorat Jenderal yang berada di setiap Kementerian, serta Badan Pengawas Daerah untuk lingkup pengawasan di daerah. Dengan demikian sistem pengendalian keuangan negara di Indonesia dapat dijabarkan sebagai berikut: sistem pengendalian eksternal, dan sistem pengendalian internal pemerintah. Sistem pengendalian eksternal pemerintah meliputi kegiatan pengawasan yang dilakukan oleh DPR, BPK, dan masyarakat, sedangkan sistem pengendalian internal pemerintah dilakukan oleh BPKP, Inspektorat Utama/Inspektorat pada Kementerian dan Lembaga Pemerintahan Non Kementerian (yang dahulu Lembaga Pemerintahan Non Departemen (LPND)), serta Badan Pengawas Daerah (Bawasda) (Murwanto et al., 2009) harus dapat menjaring penyimpangan-penyimpangan yang terjadi, dan semua itu tidak terlepas dari peran etika moral dari para auditor pemerintah yang ada.

Badan Pemeriksa Keuangan adalah lembaga tinggi negara dalam sistem ketatanegaraan Indonesia yang memiliki wewenang memeriksa pengelolaan dan tanggung jawab keuangan negara. Menurut UUD 1945, BPK merupakan lembaga yang bebas dan mandiri. Para auditor BPK merupakan auditor negara yang menjalankan tugas sebagai auditor eksternal pemerintah. Perbedaan antara para akuntan yang bekerja pada Kantor Akuntan Publik (KAP) dengan para akuntan yang bekerja selaku audior negara adalah bahwa para akuntan yang bekerja selaku auditor negara terlepas dari resiko kehilangan klien apabila tidak menuruti kehendaknya untuk berbuat tidak etis, karena klien auditor pemerintah pada umumnya atas perintah bukan atas permintaan. Namun hal ini bukan berarti tidak ada konflik dalam pengambilan keputusan berdasarkan nilai-nilai yang saling bertentangan. Konflik yang terjadi bisa timbul dari hubungan antar auditor, yaitu ketua tim dengan anggotanya maupun atasannya (supervisor) atau antara auditor dengan obyek audit (klien) itu sendiri. Sehingga pertimbangan profesional berlandaskan pada nilai dan keyakinan individu, serta kesadaran moral memainkan peranan yang penting dalarn pengambilan keputusan akhir.

Auditor banyak menghadapi dilema etika dalam melaksanakan tugasnya. Auditor secara sosial juga bertanggung jawab kepada masyarakat dan 
profesinya daripada mengutamakan kepentingan dan pertimbangan pragmatis pribadi atau kepentingan ekonomis semata. Situasi seperti hal tersebut di atas sangat sering dihadapi oleh auditor. Auditor seringkali dihadapkan kepada situasi dilema etika dalam pengambilan keputusannya (Tsui, 1996; Tsui dan Gul, 1996; Larkin, 2000; Dillard dan Yuthas, 2002). Bernegosiasi dengan auditan jelas merupakan dilema etika dan dapat menjadi sebuah konflik. Konflik audit ini akan berkembang menjadi sebuah dilema etika ketika auditor diharuskan membuat keputusan yang bertentangan dengan independensi dan integritasnya dengan imbalan ekonomis yang mungkin terjadi atau tekanan di sisi lainnya (Windsor dan Askhanasy, 1995).

Dilema etika ini juga dialami oleh auditor BPK. Auditor BPK yang merupakan auditor negara dalam tugasnya menjalankan pemeriksaan laporan keuangan dalam lingkup organisasi pemerintah dituntut untuk bertindak profesional dengan mentaati standar audit dan aturan perilaku audit yang telah ditetapkan. Hal tersebut menjadi penting, karena kontribusi BUMN/BUMD dalam perkembangan perekonomian nasional sangat besar peranannya, melalui pembagian laba yang diberikan kepada pemerintah. Dengan demikian fungsi auditor yang merupakan lini pertahanan akhir seoptimal mungkin harus dapat menjaring penyimpangan-penyimpangan yang terjadi dan semua itu tidak terlepas dari peran etika moral dari para auditor yang ada. Dalam pelaksanaan audit, konflik audit dapat muncul ketika auditor BPK menjalankan aktivitas auditing, auditor BPK sebagai pekerja di dalam organisasi yang diauditnya akan menjumpai masalah ketika harus melaporkan temuan-temuan yang mungkin tidak menguntungkan dalam penilaian kinerja organisasi atau obyek audit yang dilakukannya. Ketika organisasi pemerintah atau subyek audit menawarkan sebuah imbalan atau tekanan kepada auditor BPK untuk menghasilkan laporan audit yang diinginkan oleh organisasi pemerintah maka akan menjadi sebuah dilema etika. Dalam hal ini, auditor BPK dihadapkan kepada pilihan-pilihan keputusan yang terkait dengan halhal keputusan etis dan tidak etis.

Keputusan etis (ethical decision) per definisi adalah sebuah keputusan yang baik secara legal maupun moral dapat diterima oleh masyarakat luas (Trevino, 1986 dan Jones, 1991). Sedang perilaku etis adalah sebuah perilaku yang sesuai dengan nilai-nilai atau norma-norma moral yang diterima oleh masyarakat. 
Faktor determinan penting dalam perilaku pengambilan keputusan etis adalah faktor-faktor yang secara unik berhubungan dengan individu pembuat keputusan dan variabel-variabel yang merupakan hasil dari proses sosialisasi dan pengembangan masing-masing individu (Ford dan Richardson, 1994; Loe et al., 2000; Larkin, 2000; Paolillo dan Vitell, 2002). Faktor-faktor individual tersebut meliputi variabel-variabel yang merupakan ciri pembawaan sejak lahir (gender, umur, kebangsaan, dan sebagainya), sedangkan faktor-faktor lainnya adalah faktor organisasi, lingkungan kerja, profesi, dan sebagainya.

Kemampuan dalam mengidentifikasi dan melakukan perilaku etis atau tidak etis adalah hal yang mendasar dalam profesi akuntan. Auditor BPK juga tidak terlepas dari masalah bagaimana membuat keputusan etis. Auditor BPK sebagai karyawan mempunyai tanggung jawab kepada lembaga pemerintah di mana dia bekerja, tetapi sebagai seorang auditor profesional dia harus bertanggungjawab kepada profesinya, masyarakat, dan dirinya sendiri untuk berkelakuan etis yang baik. Kemampuan auditor BPK untuk membuat keputusan yang akan diambil ketika menghadapi situasi dilema etika akan sangat bergantung kepada berbagai hal karena keputusan yang diambil oleh auditor juga akan banyak berpengaruh kepada organisasi dan konstituen di mana dia berada (Arnold dan Ponemon, 1991).

Beberapa penelitian sebelumnya mengatakan bahwa salah satu determinan penting yang mempengaruhi keputusan etis adalah faktor-faktor yang secara unik berhubungan dengan individu pembuat keputusan dan variabel-variabel yang merupakan hasil dari proses sosialisasi dan pengembangan masing-masing individu. Faktor-faktor individu tersebut meliputi pengalaman, orientasi etika dan komitmen profesi.

Ponemon (1992) menyatakan bahwa level pertimbangan etis yang tinggi akan lebih meningkatkan sensitivitas seorang individu untuk lebih meningkatkan sensitivitas seorang individu untuk lebih mengkritisi kejadian, masalah dan konflik. Auditor dengan kapasitas pemikiran etis yang tinggi akan lebih baik dalam menghadapi konflik dan dilema etika dan lebih independen dalam membuat keputusan yang terkait dengan dilema etika. Pengalaman diduga menjadi salah satu faktor level individu yang turut mempengaruhi pengambilan keputusan etis. Butt (1988) yang dikutip oleh Budi, Basuki, dan Hendaryanno (2005) mengungkapkan bahwa auditor yang berpengalaman membuat judgment yang 
relatif baik dalam tugas-tugas profesional daripada auditor yang belum berpengalaman. Hasil penelitian Libby dan Frederick (1990) menyatakan bahwa auditor berpengalaman memperlihatkan pengetahuan yang lebih lengkap mengenai kekeliruan-kekeliruan dalam laporan keuangan dibandingkan auditor yang belum memiliki pengalaman. Hasil penelitian Kidwell et al. (1987) menunjukkan hal yang sama bahwa manajer dengan pengalaman kerja yang lebih lama mempunyai hubungan yang positif dengan pengambilan keputusan etis. Namun hasil penelitian Ford dan Richardson (1994) menyatakan hal yang sebaliknya bahwa faktor pengalaman tidak berpengaruh terhadap keputusan etis. Demikian juga hasil penelitian Budi et al. (2005) dalam penelitiannya terhadap auditor internal Bank di Jawa Timur menghasilkan bahwa faktor pengalaman auditor tidak berpengaruh terhadap keputusan etis.

Orientasi etika berhubungan dengan konsep diri dan perilaku yang berhubungan dengan individu dalam diri seseorang. Kategori orientasi etika yang dibangun oleh Forsyth (1992) menyatakan bahwa manusia terdiri dari dua konsep yaitu idealisme versus pragmatisme, dan relativisme versus nonrelativisme yang ortogonal dan bersama-sama menjadi sebuah ukuran dari orientasi etika individu. Individu yang mempunyai idealisme tinggi percaya bahwa tindakan etis seharusnya mempunyai konsekuensi yang positif dan selalu tidak akan berdampak atau berakibat merugikan kepada orang lain sekecil apapun (Barnett et al.,1994).

Faktor lain yang juga diduga berpengaruh terhadap keputusan etis adalah komitmen terhadap profesi. Jeffrey dan Weatherholt (1996) mengatakan bahwa komitmen profesi adalah intensitas identifikasi dan keterlibatan individu dengan profesinya. Identifikasi ini membutuhkan beberapa tingkat kesepakatan antara individu dengan tujuan dan nilai-nilai yang ada dalam profesi termasuk nilai moral dan etika. Jeffrey dan Weatherholt (1996) menguji hubungan antara komitmen profesional, pemahaman etika, dan sikap ketaatan terhadap aturan. Hasilnya menunjukkan bahwa akuntan yang mempunyai komitmen profesional yang kuat maka perilakunya lebih mengarah pada ketaatan aturan dibandingkan dengan akuntan yang mempunyai komitmen profesional rendah.

Penelitian-penelitian terdahulu yang berlandaskan psikologi sosial dengan menekankan pada pentingnya pengalaman kerja, komitmen profesional, nilai etika organisasi, dan orientasi etika mempunyai pengaruh dalam pengambilan 
keputusan etis individual. Berdasarkan uraian di atas maka penelitian dengan topik etika khususnya keputusan etis merupakan isu yang menarik untuk diteliti karena keputusan etis memainkan peranan yang penting di mana auditor akan selalu dihadapkan pada pengambilan keputusan-keputusan etis ketika menjalankan tugas mengaudit laporan keuangan. Penelitian ini menindaklanjuti penelitian Butt (1988), Zeigenfuss dan Singhapakdi (1994), serta penelitian Windsor dan Ashkanasy (1995) terkait hubungan yang kompleks antara pengalaman, orientasi etika, dan komitmen profesional pengaruhnya terhadap keputusan etis. Selain itu, penelitian ini menguji kembali hasil penelitian Budi et al. (2005) dengan mengubah variabel komitmen profesional sebagai variabel intervening serta mengurangi variabel nilai etika dari pengujian penelitian karena objek penelitian dilakukan dalam satu instansi yang sama. Pengubahan variabel tersebut dengan pertimbangan dalam penelitian sebelumnya tidak ditemukan pengaruh antara pengalaman auditor hubungannya dengan komitmen profesional maupun terhadap keputusan etis, sedangkan berdasarkan hasil penelitian Hall et al. (2005) variabel komitmen profesional diduga sebagai variabel yang mampu memediasi pengalaman dan keputusan etis bahwa komitmen profesi memediasi hubungan antara pengalaman dan judgment.

\section{METODE PENELITIAN}

Pada bagian ini akan dibahas aspek metodologi yang digunakan dalam penelitian ini. Berturut-turut akan dibahas mengenai identifikasi variabel, definisi operasional, populasi dan sampel penelitian, instrumentasi dan skala pengukuran, uji validitas dan reliabilitas, rancangan penelitian serta pada bagian akhir akan dibahas metode analisis yang digunakan dalam penelitian ini.

\section{Identifikasi Variabel}

Dari kerangka teoritik dalam penelitian ini ada beberapa konstruk yang merupakan abstrak dari fenomena-fenomena yang diteliti dan variabel yang merupakan mediator antara konstruk yang abstrak dengan fenomena yang nyata. Variabel memberikan gambaran yang lebih nyata mengenai fenomena-fenomena yang digeneralisasi dalam konstruk. Penelitian ini mengambil topik bagaimana pengambilan keputusan etis auditor negara dalam situasi dilema etika. Variabel dalam penelitian ini yaitu:

1. Pengambilan Keputusan Etis Auditor Negara 
2. Pengalaman Auditor Negara

3. Orientasi Etika Auditor Negara, serta

4. Komitmen Profesional Auditor Negara

\section{Populasi dan Sampel Penelitian}

Data yang digunakan adalah data primer, yaitu pengumpulkan data melalui survei dengan mengirimkan kuesioner kepada responden. Subyek penelitian adalah para auditor negara yang bekerja pada Badan Pemeriksa Keuangan Kantor Perwakilan Provinsi Jawa Timur. Penelitian ini menggunakan metode sampling, dengan penentuan sampel dilakukan dengan menggunakan metode purposive sampling, yaitu pengambilan sampel dari populasi berdasarkan suatu kriteria tertentu (Hartono, 2007). Prosedur pemilihan sampel dilakukan dengan kriteria berikut:

a. Auditor yang bekerja pada Badan Pemeriksa Keuangan (BPK) Kantor Perwakilan Provinsi Jawa Timur.

b. Auditor yang telah bekerja sebagai auditor negara minimal satu tahun.

Populasi yang tercatat sebagai auditor BPK pada Kantor Perwakilan Provinsi Jawa Timur sebanyak 150 orang, berdasarkan prosedur pemilihan sampel di atas, diperoleh 100 orang yang memenuhi kriteria. Dengan demikian kuesioner akan dibagikan kepada 100 orang responden.

\section{Instrumentasi dan Skala Pengukuran}

Instrumen-instrumen pengukuran yang digunakan dalam penelitian ini diadopsi dari instrumen yang telah disusun oleh peneliti terdahulu, masing-masing diukur dengan menggunakan skala Likert dengan 5 kategori yaitu 1=Sangat Setuju, 2=Setuju, 3=Ragu-ragu, 4=Tidak Setuju, 5=Sangat Tidak Setuju. Penelitian ini menggunakan 35 item kuesioner (tidak termasuk pertanyaan identifikasi) untuk mengukur 4 konstruk dalam model. Setelah item kuesioner dengan pertanyaan negatif disesuaikan pembobotannya, selanjutnya item kuesioner yang merepresentasikan konstruk tersebut diuji validitas dan reliabilitasnya.

\section{Rancangan Penelitian}


Rancangan penelitian (research design) adalah merupakan kerangka kerja atau cetak biru yang berguna sebagai pedoman utama dalam melaksanakan seluruh rangkaian kegiatan dalam peneiltian ini. Penelitian ini dirancang untuk mengeksplorasi sebuah model tentang pengambilan keputusan etis auditor negara. Tujuannya adalah untuk menguji kausalitas teori yang ada melalui uji data empirik. Rancangan penelitian yang digunakan dalam penelitian ini adalah:

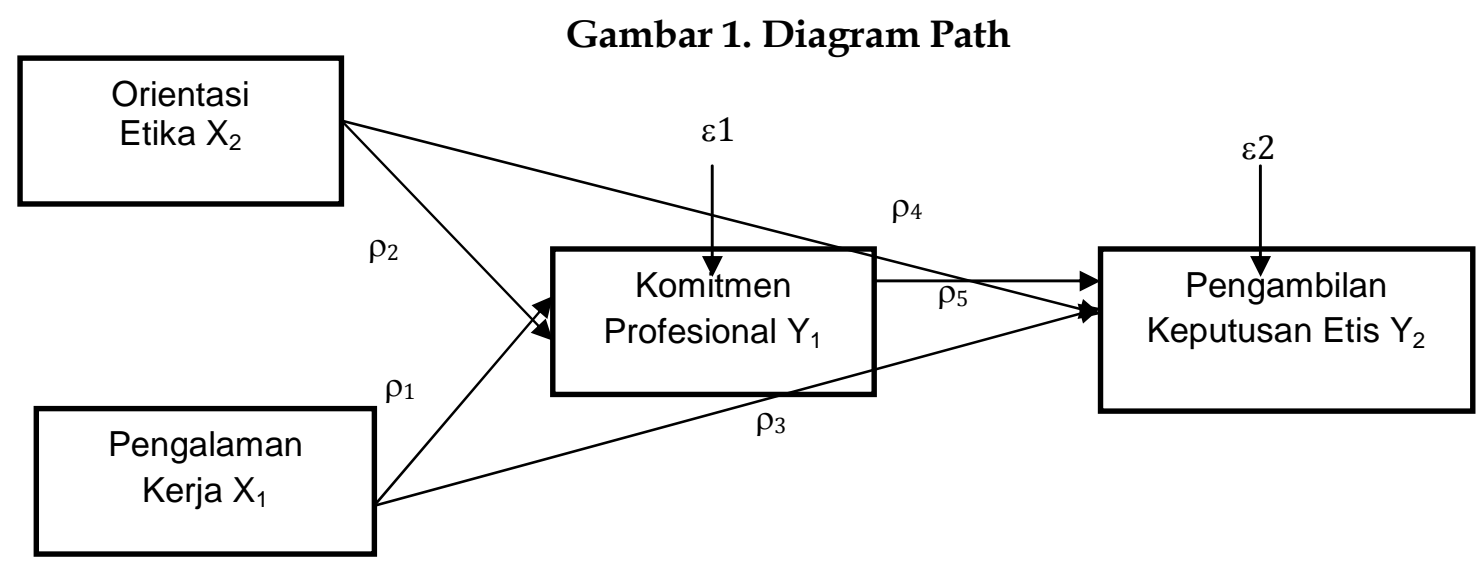

\section{Metode Analisis Data \\ Model Analisis Jalur}

Penelitian ini menunjukkan pola hubungan yang dapat dikategorikan sebagai mediated path model (Schumacker dan Lomax, 1996:41-42), hal ini didukung pula oleh pendapat Sarwono (2007:5) yang menyatakan pola hubungan langsung dan tidak langsung sebagai path analysis.

Dalam menganalisis masalah penelitian dengan menggunakan analisis path (path analysis) maka dapat diturunkan suatu model struktur dengan dua langkah yang persamaan fungsinya dapat dirumuskan pada persamaan struktur sebagai berikut:

$$
\begin{aligned}
& Y_{1}=\rho_{1} X_{1}+\rho_{2} X_{2}+e_{1} \\
& Y_{2}=\rho_{3} X_{1}+\rho_{4} X_{2}+\rho_{5} Y_{1}+e_{2}
\end{aligned}
$$

\section{Asumsi Pada Analisis Jalur}

Pemeriksaan terhadap beberapa asumsi yang melandasi analisis jalur antara lain:

- Dalam analisis path hubungan antara variabel adalah linier dan aditif. 
- Hanya model rekursif dapat dipertimbangkan, yakni hanya sistem aliran kausal ke satu arah. Sedangkan model yang mengandung kausal resiprokal tidak dapat dilakukan analisis path.

- Variabel intervening dan dependen minimal dalam skala ukur interval.

- Observed variabel yang diukur tanpa kesalahan (instrumen pengukuran valid dan reliable).

- Model yang dianalisis dispesifikasikan (diidentifikasi) dengan benar berdasarkan teori-teori dan konsep-konsep yang relevan.

\section{Langkah-Langkah Analisis Jalur}

Analisis data yang digunakan dalam penelitian ini menggunakan analisis jalur (Path Analysis) dengan bantuan perhitungan melalui program SPSS. Analisis jalur merupakan suatu bentuk penerapan dari regresi berganda yang menggunakan diagram jalur sebagai petunjuk terhadap pengujian hipotesis yang komplek. Analisis jalur (Path Analysis) digunakan untuk menguji hubungan sebab akibat berdasarkan pengetahuan, perumusan teori dan asumsi, juga dapat digunakan untuk menguji hipotesis penelitian serta menafsir hubungan tersebut. Analisis jalur ini dikembangkan sebagai suatu metode untuk mempelajari pengaruh secara langsung maupun tidak langsung dari variabel independen terhadap variabel dependen.

Menurut Solimun (2002) langkah-langkah dalam analisis path adalah sebagai berikut:

1) Merancang model berdasarkan konsep dan teori.

2) Pemeriksaan terhadap asumsi yang melandasi analisis jalur.

3) Pendugaan parameter atau perhitungan koefisien path.

Pendugaan parameter dengan model OLS, dimana di dalam software SPSS dihitung melalui analisis regresi, yakni dilakukan pada masing-masing persamaan secara parsial.

4) Pemeriksaan validitas model

Sah tidaknya suatu hasil analisis bergantung pada terpenuhi atau tidaknya asumsi.

5) Melakukan interpretasi hasil analisis

a. Dengan memperhatikan hasil validitas model. 
b. Menghitung pengaruh total dari setiap variabel yang mempunyai pengaruh kausal ke variabel endogen.

Pengaruh langsung merupakan arah hubungan yang langsung antara variabel tanpa melalui variabel lain, sedangkan pengaruh tidak langsung melalui variabel lain. Untuk melihat besarnya pengaruh langsung antar variabel dengan menggunakan koefisien regresi yang distandarisasi. Adapun besarnya pengaruh tidak langsung dalam analisis jalur adalah dengan cara mengalikan koefisien jalur pengaruh langsung variabel antara dengan variabel analisis terhadap variabel independen. Signifikansi dari pengaruh tidak langsung dapat dilihat dari signifikansi pada jalur pertama dengan signifikansi dari variabel perantara dengan variabel dependen.

\section{Pendugaan Parameter}

Langkah berikutnya dalam path analysis adalah pendugaan parameter (perhitungan koefisien path). Di dalam path analysis, di samping ada pengaruh langsung juga terdapat pengaruh tidak langsung dan pengaruh total. Pengaruh langsung diperoleh dari standardize coefficients (beta) dan diberi simbol $\boldsymbol{\rho}$. Sedangkan pengaruh tidak langsung dan pengaruh total merupakan hasil perkalian dan penjumlahan antar koefisien $\boldsymbol{\rho}$. Pengaruh total merupakan penjumlahan dari pengaruh langsung dan pengaruh tidak langsung (Sarwono, 2007: 34).

Berdasarkan Diagram Path di atas, nilai $\boldsymbol{\rho}$ merupakan nilai standardized coefficient (ßeta) (Ghozali, 2008), maka dapat ditentukan pola hubungan sebagai berikut:

1. Pengaruh Langsung $X_{1}$ ke $Y_{1}=\rho_{1}$

2. Pengaruh Langsung $X_{2}$ ke $Y_{1}=\boldsymbol{\rho}_{2}$

3. Pengaruh Langsung $X_{1}$ ke $Y_{2}=\rho_{3}$

4. Pengaruh Langsung $\mathrm{X}_{2}$ ke $\mathrm{Y}_{2}=\boldsymbol{\rho}_{4}$

5. Pengaruh Langsung $Y_{1}$ ke $Y_{2}=\rho_{5}$

6. Pengaruh tidak Langsung $X_{1}$ ke $Y_{2}$ melalui $Y_{1}=\boldsymbol{\rho}_{1} * \boldsymbol{\rho}_{5}$

7. Pengaruh tidak Langsung $X_{2}$ ke $Y_{2}$ melalui $Y_{1}=\boldsymbol{\rho}_{2}$ * $\boldsymbol{\rho}_{5}$

\section{Pengujian Koefisien Determinasi Model $\left(\mathbf{R}^{2}{ }_{\text {model }}\right)$}


Koefisien determinasi ( $\mathrm{R}$ square) bertujuan untuk mengukur seberapa jauh kemampuan model dalam menjelaskan variasi variabel exogen. Nilai koefisien determinasi berkisar antara 0 (nol) hingga 1 (satu). Nilai R square yang kecil menandakan bahwa kemampuan variabel-variabel exogen dalam menjelaskan variasi variabel endogen amat terbatas. Nilai yang mendekati satu menandakan variabelvariabel exogen memberikan hampir semua informasi yang dibutuhkan untuk memprediksi variasi variabel endogen (Ghozali, 2005:83). Ketepatan model yang ada pada diagram jalur dapat dihitung dengan generalized $\mathrm{R}^{2}$ dengan rumus :

$$
\mathrm{R}^{2} \text { model }=1-\left(1-\mathrm{R}^{2}\right)\left(1-\mathrm{R}^{2}{ }_{2}\right)
$$

dimana $R_{i}{ }^{2}=$ Koefisien determinasi dari persamaan ke-i $(i=1,2)$

\section{Pengujian Koefisien Jalur}

Pengujian hipotesis dilakukan melalui regresi yang menggunakan program SPSS dengan membandingkan tingkat signifikasi (Sig t) masing-masing variabel independen dengan taraf sig $\alpha=0,05$. Apabila tingkat signifikansinya (Sig t) lebih kecil daripada $\alpha=0,05$, maka hipotesisnya diterima yang artinya variabel independen tersebut berpengaruh secara signifikan terhadap variabel dependennya. Sebaliknya bila tingkat signifikansinya (Sig t) lebih besar daripada a $=0,05$, maka hipotesisnya tidak diterima yang artinya variabel independen tersebut tidak berpengaruh secara signifikan terhadap variabel dependennya. Jika dinyatakan secara statistik adalah sebagai berikut :

$$
\begin{aligned}
& \text { Ho }: \beta i=0 \\
& \text { H1 }: \beta i \neq 0
\end{aligned}
$$

T hitung dicari dengan persamaan sebagai berikut :

$$
\text { Koefisien Regresi (bi) }
$$

$$
\text { t- hitung }=
$$

Standar Deviasi (bi)

Jika t- hitung > dari t- tabel maka Ho ditolak, dan jika t- hitung < dari t-tabel maka Ho diterima. 


\section{PEMBAHASAN}

\section{Pembahasan Hasil Penelitian}

Pengujian hipotesis yang telah dilakukan di atas adalah menguji persamaan struktural yang memiliki dua variabel endogen (variabel terikat). Variabel endogen dalam penelitian ini adalah komitmen profesional yang dipengaruhi oleh pengalaman auditor dan orientasi etika dan variabel endogen keputusan etis yang dipengaruhi oleh pengalaman auditor, orientasi etika dan komitmen profesional. Berikut ini akan dibahas pengaruh terhadap variabel endogen oleh masing-masing variabel yang mempengaruhinya.

\section{Pengaruh Pengalaman Kerja Terhadap Keputusan Etis}

Pengaruh pengalaman kerja auditor negara terhadap keputusan etis dalam penelitian ini menunjukkan bahwa pengalaman kerja yang dimiliki oleh seorang auditor negara dalam penelitian ini ternyata kurang bisa menggambarkan pengaruhnya terhadap kemampuan mereka dalam pengambilan keputusan etis auditor. Seharusnya dengan semakin lama pengalaman kerja seorang auditor negara maka akan meningkatkan pertimbangan keputusan etis yang akan diambil karena tugas yang dilakukan secara berulang-ulang memberi peluang untuk melakukan yang terbaik sehingga pengalaman dapat meningkatkan kinerja pengambilan keputusan etis, namun dalam penelitian ini tidak ditemukan hubungan secara langsung antara pengalaman kerja dengan keputusan etis. Hal ini bisa terjadi karena pengisian kuesioner dipengaruhi oleh faktor-faktor individual dari masing-masing responden. Faktor individual pengalaman kerja, dalam beberapa penelitian memang seringkali tidak ditemukan pengaruhnya dalam keputusan etis (Ford dan Richardson, 1994), dan Budi et al. (2005). Hal ini mengindikasikan bahwa penelitian ini tidak konsisten dengan Glover (2002), Larkin (2000) serta Kidwell et al.(1987) yang menyatakan bahwa individu dengan lebih banyak pengalaman kerja akan cenderung mempunyai tanggapan etis yang lebih baik.

\section{Pengaruh Pengalaman Kerja Terhadap Komitmen Profesional}

Pengaruh pengalaman kerja terhadap komitmen profesional dalam penelitian ini menunjukkan semakin lama seorang auditor negara bekerja maka akan semakin meningkatkan komitmen auditor negara terhadap profesinya. Dari hasil pengujian hipotesis yang telah dilakukan dapat disimpulkan bahwa pengalaman auditor 
negara berpengaruh langsung terhadap komitmen profesi auditor negara. Hal ini dapat dikatakan seseorang yang telah lama disebuah organisasi akan memiliki komitmen profesi yang tinggi daripada seseorang yang baru masuk dalam profesi tersebut sehingga auditor senior memiliki komitmen profesi yang lebih tinggi karena adanya proses sosialisasi yang lebih tinggi dibandingkan dengan auditor junior. Auditor ingin selalu tetap tinggal dalam sebuah profesi yang memberikan mereka pengalaman kerja yang positif karena keselarasan nilai-nilai dan mengharapkan mereka untuk melajutkan bekerja dalam profesi tersebut. Dengan demikian, lama pengalaman kerja seorang auditor akan meningkatkan komitmen auditor terhadap profesinya.

Hasil ini mendukung penelitian yang dilakukan oleh Kalbers dan Fogarty (1995), Sumardi dan Hardiningsih (2002) dan Poerwati (2003) menyatakan bahwa semakin berpengalaman seorang auditor, maka akan semakin tinggi profesionalismenya.

\section{Pengaruh Orientasi Etika Terhadap Keputusan Etis}

Pengaruh orientasi etika terhadap keputusan etis dalam penelitian ini menunjukkan bahwa orientasi etika auditor negara akan berpengaruh terhadap keputusan-keputusan etis yang diambil. Hasil pengujian hipotesis menunjukkan hubungan positif antara orientasi etika terhadap keputusan etis. Hal ini dapat disimpulkan bahwa orientasi etika yang dimiliki oleh auditor negara dapat meningkatkan kemampuan diri seorang auditor untuk memecahkan suatu masalah dengan mempertimbangkan serta menganalisis informasi sehingga dapat menghasilkan sebuah keputusan-keputusan etis.

Hasil penelitian ini konsisten dengan penelitian Jones (1991), Zeigenfuss dan Singhapakdi (1994) dan Douglas et al. (2001) yang menyatakan orientasi etika seseorang akan berpengaruh terhadap keputusan etis.

\section{Pengaruh Orientasi Etika Terhadap Komitmen Profesional}

Pengaruh orientasi etika terhadap komitmen profesional dalam penelitian ini menunjukkan bahwa semakin tinggi orietasi etika yang dimiliki seorang auditor negara akan meningkatkan komitmen terhadap profesinya. Hal ini dapat dikatakan bahwa tingginya orientasi etika yang dimiliki oleh auditor negara akan meningkat keahlian dan menjadi bagian penting yang mempengaruhi sikap profesionalisme. 
Semakin bertambahnya orientasi etika akan meningkatkan keahlian dan ketrampilan dalam menjalankan praktek-praktek audit dan akuntansi dalam menjalankan tugas sebagai auditor negara, dan tentu saja orientasi etika yang dibentuk dari proses menjalankan tugas sebagai auditor negara akan menunjang dalam pembentukan sikap profesionalisme seorang auditor. Hasil penelitian ini konsisten dengan penelitian sebelumnya yang dilakukan oleh Shaub et al., (1993) dan Jeffrey dan Weatherholt (1996) yang menyatakan bahwa individu yang mempunyai idealisme secara otomatis akan memelihara tatacara pekerjaannya sesuai dengan standar profesional, sehingga standar profesional tersebut akan menjadi arahan dalam bekerja.

\section{Pengaruh Komitmen Profesional Terhadap Keputusan Etis}

Keputusan etis dapat dipengaruhi oleh pihak lain yang dihadapi seorang individu dalam lingkungan profesinya tanpa memperhatikan apakah perilakunya sesuai dengan kode etik atau tidak. Hasil pengujian hipotesis menunjukkan bahwa komitmen profesional yang dimiliki auditor negara berpengaruh terhadap keputusan-keputusan etis yang diambilnya. Hal ini mengindikasikan semakin tinggi komitmen seorang auditor negara terhadap profesinya maka akan semakin berpengaruh terhadap pengambilan keputusan-keputusan etis yang dilakukannya. Sistem pengawasan yang baik dari organisasi profesi auditor negara terhadap anggotanya serta pengawasan masyarakat pada umumnya turut mempengaruhi perilaku auditor negara. Teori perkembangan moral Kohlberg juga menunjukkan bahwa ketika perkembangan moral seseorang berada pada level conventional maka individu cenderung berbuat dengan apa yang diharapkan oleh orang lain dalam hal ini adalah atasan atau klien.

Hasil penelitian ini mendukung hasil penelitian Windsor dan Ashkanasy (1995) serta penelitian Khomsiyah dan Indriantoro (1998) yang menyatakan bahwa komitmen profesional mempunyai pengaruh terhadap sensitivitas etika auditor pemerintah yang menjadi sampel penelitiannya.

\section{Pengaruh Tidak Langsung Pengalaman Auditor Terhadap Keputusan Etis Melalui Komitmen Profesional}

Hasil analisis menunjukkan bahwa terdapat pengaruh tidak langsung antara pengalaman auditor terhadap pengambilan keputusan etis auditor negara melalui komitmen profesional sebagai variabel intervening. Dalam penelitian ini 
ditunjukan dengan pembuktikan bahwa semakin lama pengalaman auditor berpengaruh kuat terhadap tingginya tingkat komitmen auditor terhadap profesinya. Dengan komitem yang tinggi seorang auditor memiliki kemampuan yang lebih baik dalam mengambil keputusan-keputusan etis. Komitmen profesional ini juga mampu membuktikan bahwa variabel ini sebagai variabel intervening karena dalam pengujian hipoteisis sebelumnya pengalaman auditor tidak memiliki pengaruh langsung terhadap pengambilan keputusan etis auditor negara.

Pengalaman akan memberikan kesempatan bagi auditor negara untuk lebih lama bersosialisasi terhadap profesinya dan pada akhirnya menumbuhkan nilai-nilai yang positf terhadap profesinya. Nilai-nilai yang baik ini semakin lama semakin menumbuhkan komitmen yang tinggi bagi auditor. Melalui komitmen yang tinggi seorang auditor akan berpikiran dan berperilaku yang etis.Dengan demikian dapat dikatakan bahwa seorang auditor yang memiliki komitmen yang tinggi selalu berusaha menjaga nilai-nilai yang baik dari profesinya dan akan selalu berusaha mengambil keputusan-keputusan etis dalam menjalankan tugasnya. Tingginya nilai komitmen ini dapat dibentuk dari proses pengalaman seorang auditor. Hasil ini mendukung penelitian yang dilakukan oleh Hall et al. (2005) yang menunjukkan bahwa komitmen profesi mediasi antara pengalaman dan judgment.

\section{Pengaruh Tidak Langsung Orientasi Etika Terhadap Keputusan Etis Melalui Komitmen Profesional}

Hasil analisis menunjukkan bahwa terdapat pengaruh tidak langsung antara orientasi etika terhadap pengambilan keputusan etis auditor negara melalui komitmen profesional sebagai variabel intervening . Dalam penelitian ini ditunjukkan dengan pembuktian bahwa semakin tinggi orientasi etika yang dimiliki seorang auditor berpengaruh positif terhadap tingginya tingkat komitmen auditor terhadap profesinya. Tingginya komitmen ini juga berpengaruh baik terhadap pengambilan keputusan-keputusan etis seorang auditor negara. Dengan demikian mengindikasikan bahwa seorang auditor dengan orientasi etika yang kuat secara langsung maupun tidak langsung akan mendorong dalam pengambilan keputusan etis menjadi lebih baik. Hal ini membuktikan bahwa variabel komitmen profesional 
juga merupakan variabel intervening yang mediasi antara orientasi etika terhadap keputusan etis auditor negara.

Orientasi etika akan memberikan pengetahuan yang lebih baik dan pada akhirnya menumbuhkan nilai-nilai komitmen yang tinggi bagi seorang auditor dan hal ini akan sangat berpengaruh terhadap pengambilan keputusan-keputusan etis seorang auditor negara. Hasil ini mendukung hasil penelitian oleh Trivino (1986) yang menyatakan bahwa orientasi etika dan komitmen profesional secara bersama mempunyai pengaruh terhadap keputusan etis individual.

\section{SIMPULAN}

Penelitian ini menguji pengaruh pengalaman auditor dan orientasi etika terhadap keputusan etis dengan komitmen profesional sebagai variabel intervening. Berdasarkan pembuktian empiris terhadap model konseptual yang disusun dalam bab awal penelitian maka dapat diberikan kesimpulan umum bahwa dalam penelitian ini tingkat pengalaman auditor tidak memiliki pengaruh langsung terhadap pengambilan keputusan etis seorang auditor negara atau dapat dikatakan pula bahwa hasil penelitian ini menunjukkan lama bekerja seorang audittor negara belum bisa mengambarkan bahwa hasil keputusan etis yang akan diambil selalu baik dan benar. Hal ini bisa terjadi karena pengisian kuesioner dipengaruhi oleh faktor individual masing-masing responden, dengan demikian dalam penelitian ini menolak hipotesis pertama dan dalam beberapa penelitian sebelumnya memang seringkali tidak ditemukan pengaruh pengalaman auditor terhadap keputusan etis. Tetapi dalam penelitian ini, pengalaman kerja memiliki pengaruh kuat terhadap komitmen profesi. Berdasarkan hasil tersebut membuktikan bahwa hipotesis kedua diterima.

Orientasi etika yang dimiliki auditor negara berpengaruh terhadap keputusan etis yang diambil oleh seorang auditor, koefisien korelasi bersifat positif dengan demikian mendukung hipotesis ketiga. Selain itu semakin tinggi orientasi etika yang dimiliki oleh auditor negara berpengaruh langsung terhadap komitmen profesional, hal ini mendukung hipotesis keempat dari penelitian ini. Sehingga dapat disimpulkan bahwa semakin tinggi orientasi etika yang dimiliki oleh seorang auditor negara akan berpengaruh terhadap sebuah keputusan etis 
yang diambil oleh auditor negara serta orientasi etika juga memiliki pengaruh terhadap proses pembentukan komitmen terhadap profesia auditor negara.

Komitmen pofesional yang dimiliki oleh auditor negara memiliki pengaruh langsung atau signifikan terhadap keputusan etisnya sehingga peneltian ini mendukung hipotesis kelima. Komitmen profesional seorang auditor negara dalam penelitian ini dapat dibangun oleh faktor pengalaman kerja dan orientasi etika, dengan demikian keputusan etis yang dihasilkan oleh seorang auditor negara secara tidak langsung dipengaruhi kedua faktor di atas. Sehingga hasil penelitian ini merupakan bukti bahwa hipotesis keenam dan ketujuh diterima. Atau dengan kata lain penelitian ini dapat membuktikan bahwa komitmen profesional mampu memidiasi pengalaman auditor dan orientasi etika terhadap sebuah keputusan etis. Pengalaman kerja dan orientasi etika adalah dua hal penting yang berhubungan dengan komitmen profesional dan pengambilan keputusan etis. Dalam jangka panjang pengalaman kerja yang lama dan orientasi etika yang tinggi bisa memperbaiki komitmen profesional dengan baik sehingga bisa meningkatkan pengambilan keputusan etis.

\section{DAFTAR PUSTAKA}

Arens, A.A. dan J.K Locbeckee. 2003. Auditing Pendekatan Terpadu. Jusuf, A. Abadi . (Penerjemah). Jakarta. Salemba Empat.

Arnold, D.F dan L.A. Ponemon. 1991. Internal Auditors Perceptions of WhistleBlowing and the Influence of Moral Reasoning: An Experiment, Auditing: A Journal of Practice $\mathcal{E}$ Theory 10 (2): 1-15.

Arnold, V.; J.C. Lampe dan S.G. Sutton. 1999. Understanding The Factors Underlying Etrhical Organizations: Enabling Continuous Ethical Improvement, The Journal ofApplied Business Research 15 (3): 1-19.

Barnett, T., K. Bass dan G. Brown. 1994. Ethical Ideology and Ethical Judgment Regarding Ethical Issues in Business, Journal ofBusiness Ethics 13: 469-480.

Bonner, S.E. 1990. Experience Effect in Auditing: The Role of Task-Specific Knowledge, The Accounting Review 65 (1): 72-92.

Budi, S., Basuki dan Hendaryanno. 2005. Internal Auditor dan Dilema Etika, Jurnal Ekonomi Bisnis dan Akuntansi "Ventura" 8 (1):1-36 
Cohen, J.R., L.W. Pant dan D.J. Sharp. 1995. An Exploratory Examination of Internal Differences in Auditors' Ethical Perceptions, Behavioral Research in Accounting 7: 37-64.

Damman, T.E. 2003. Audit: A Build-in Conflict of Interest, Corporate Board 24 (128): $16-22$

Davis, C.E. 1997. Experience and the Organization of Auditors' Knowledge, Managerial Auditing Journal 12 ( 8): 411-422.

Dillard, J.F dan K. Yuthas. 2002. Ethical Audit Decisions: A Structural Perspective, Journal ofBusiness Ethics 36 (1-2): 49-64.

Douglas, P.C., R.A. Davidson dan B.N. Schwartz. 2001. The Effect of Organizational Culture and Ethical Orientation on Accountants' Ethical Judgments, Journal of Business Ethics: 34 (2): 101-121.

Finegan, J. 1994, The Impact of Personal Values on Judgments of Ethical Behaviour in the Workplace, Journal of Business Ethics 13 : 747-755.

Gutomo K, (2003). Pengambilan Keputusan Etik Auditor Pemerintah Dalam Situasi Konflik Auditor: Pengaruh Interaksi Locus Of Control dan Komitmen Profesi dengan Kesadaran Etik. Tesis Tidak Dipublikasikan, Universitas Diponegoro.

Hudayati, A. 2002. Perkembangan Penelitian Akuntansi Keperilakuan: Berbagai teori dan pendekatan yang melandasi. JAAI 6 (2): 81-96. 